\title{
Niepełnosprawność i aktywizm. Performatywna siła protestu
}

Ewelina Godlewska-Byliniak

TEKSTY DRUGIE 2020, NR 2, S. 104-123

DOI: 10.18318/td.2020.2.7 | ORCID: 0000-0001-5871-4602

\section{Lata70.ipoczątekery praw osóbz niepełnosprawnościami w Stanach Zjednoczonych i Wielkiej Brytanii}

Tom Shakespeare stawia tezę, że w latach 70. osoby z niepełnosprawnościami zaczęły stanowić nową zwartą siłę polityczną ${ }^{1}$. Badacz pokazuje ten proces na przykładzie działań aktywistów w USA i Wielkiej Brytanii, gdzie ruch walczący o prawa osób z niepełnosprawnościami, tworzony przez nie same, wyłonił się i skonsolidował wyraźnie właśnie w tym okresie, stając się siłą rozpoznawalną między innymi dzięki przyjętym strategiom działania i walki uwidaczniającym określone problemy i przede wszystkim zaznaczającym niezwykle wyraźnie obecność osób z niepełnosprawnościami w przestrzeni publicznej jako aktywnych członków społeczeństwa

1 Zob. T. Shakespeare Samoorganizacja osób niepełnosprawnych: nowy ruch społeczny?, przeł. A. Zawrzykraj, w: Niepełnosprawność i społeczeństwo. Performatywna siła protestu, red. E. Godlewska-Byliniak, J. Lipko-Konieczna, Fundacja Teatr 21, Biennale Warszawa, Warszawa 2018, s. 33-51.

\author{
Ewelina Godlew- \\ ska-Byliniak - dr, \\ adiunktka w Instytu- \\ cie Kultury Polskiej \\ UW, obecnie zajmuje \\ się reprezentacją \\ niepełnosprawności \\ w kulturze. Opubliko- \\ wała: Tadeusz Kantor: \\ sobowtór, melancho- \\ lia, powtórzenie (2011), \\ Teatr radio-logiczny \\ Tymoteusza Karpowi- \\ cza (2012). Współre- \\ daktorka książki Odzy- \\ skiwanie obecności. \\ Niepełnosprawność \\ w teatrze i performan- \\ sie (2017). Kontakt: \\ ewelina.godlewska@ \\ gmail.com.
}


domagających się równych praw i odwołujących się do podstawowego prawa do posiadania praw.

Z kolei Paul K. Longmore uznaje, że ostatnie dekady XX wieku, począwszy od lat 70., to w Stanach Zjednoczonych wręcz "czas praw osób z niepełnosprawnościami"2. Okres ten, naznaczony kolejnymi punktami zwrotnymi, jest w ujęciu tego badacza czasem wyłaniania się i konsolidacji ruchu osób z niepełnosprawnościami jako ruchu politycznego i tożsamościowego jednocześnie, działającego ponad podziałami i różnicami interesów wynikającymi z odmiennych form niepełnosprawności i podkreślającego uniwersalne aspekty jej doświadczania mające swe źródło w uwarunkowaniach społeczno-kulturowych. Rozwojowi ruchu towarzyszyły - jak wskazuje Longmore - równoległe procesy wzrostu świadomości i poczucia tożsamości osób z niepełnosprawnościami, które zaczęły rozpoznawać siebie jako członków określonej grupy dzielącej wspólne doświadczenie społeczne i walczącej o wspólne interesy, formułowane już nie jako partykularne potrzeby, ale jako podstawowe prawa obywatelskie ${ }^{3}$.

Badacze są zasadniczo zgodni co do tego, że ów proces konsolidacji i wyłaniania się tej grupy jako nowej siły politycznej nabiera tempa w tym właśnie okresie, kiedy to osoby z niepełnosprawnościami podejmują szereg konkretnych działań mających na celu doprowadzenie do zmiany społecznej związanej zarówno z redefinicją samego pojęcia niepełnosprawności i jej postrzegania, jak też - chyba przede wszystkim - ze zmianą miejsca, jakie osoby z niepełnosprawnością zajmują w społeczeństwie. Warto zadać pytanie o czynniki, które sprzyjały temu procesowi, i o jego przebieg. Rozpoznanie własnego usytuowania na obrzeżach tego, co nazwać można sprawnym centrum poddającym marginalizacji i systemowej dewaluacji to, co nie mieści się w jego ramach, było tu niewątpliwie kluczowe. Niebagatelne znaczenie dla owego rozpoznania miały zapewne działania podejmowane na szeroką skalę od lat 6o. przez kolejne grupy mniejszościowe w ramach walki o swoje prawa: ruch na rzecz praw obywatelskich w USA, ruchy feministyczne, ruchy gejowskie $e^{4}$. Organizacje tworzone przez osoby z niepełnosprawnościami w pierwszym okresie działań aktywistycznych korzystały z doświadczeń

2 P.K. Longmore The disability rights moment. Activism in the 1970 s and beyond, w: tegoż Why I burned my book and other essays on disability, Temple University Press, Philadelphia 2003, s. 102.

3 Zob. tamże, s. 114-115.

4 Podobieństwa pomiędzy tymi ruchami sygnalizuje m.in. Tom Shakespeare w: Samoorganizacja osób niepełnosprawnych. 
owych grup, często uruchamiając podobne strategie walki, ale też - co wydaje się tu niezwykle ważne - wkraczały w pole, w którym głosy konkretnych mniejszości - dzięki ich dążeniu do zmiany - były coraz bardziej słyszalne. Owa dokonująca się wówczas rekonfiguracja pola, którą za Rancière'em można nazwać podziałem zmysłowości, wiązała się z próbą zdefiniowania na nowo tego, co i kto może być widzialny i słyszalny w przestrzeni tego, co wspólne. W koncepcji Rancière’a podział zmysłowości dotyczy specyficznego układu przestrzeni i czasu, przedmiotów i podmiotów zamieszkujących tę przestrzeń i uznawanych za ważne, który to układ warunkuje to, co w danym polu społecznym może zostać usłyszane, dostrzeżone, wypowiedziane, a co nie mieści się w jego granicach. Podział rozumiany jest tutaj zarówno jako dzielenie pewnej całości na części, jak i współdzielenie czegoś - współużywanie tego, co wspólne. Granice tak zdefiniowanego pola nie są stałe, a jego redefinicja, dokonująca się zarówno w sferze estetyki, jak i polityki, które u Rancière'a są ze sobą ściśle powiązane, wiąże się z wciąż ponawianym pytaniem o kształt wspólnoty ${ }^{5}$. O przebiegu owych granic decydują zarówno określone dyskursy, jak i praktyki i działania społeczne nastawione na ich zachowanie bądź przesunięcie. Działania podejmowane przez wspomniane wyżej ruchy mniejszościowe, w tym przez konsolidującą się grupę osób z niepełnosprawnościami, sytuuję tutaj jako tego rodzaju działania nakierowane na zmianę definicji tego, co wspólne, i redefinicję podziału zmysłowości. Polityczność ruchu osób z niepełnosprawnościami jawi się z tej perspektywy nie tylko jako działanie mające na celu realizację konkretnych postulatów o charakterze politycznym, ekonomicznym, czy legislacyjnym związanych $\mathrm{z}$ żądaniem równych praw i zniesieniem dyskryminacji ze względu na niepełnosprawność, czyli z rozszerzeniem obowiązujących zasad na grupę do tej pory marginalizowaną, ale właśnie jako proces redefinicji tego, co wspólne, poprzez działania i praktyki doprowadzające do wyłonienia nowych równo-ważnych i pełnoprawnych podmiotów. I tak jak Rancière wiąże polityczność z estetyką, tak w przypadku ruchu osób z niepełnosprawnościami można powiązać polityczność ze sztuką działania rozumianego jako działanie o charakterze performatywnym.

Jeśli spojrzeć na przedstawiany przez badaczy proces konsolidacji ruchu osób z niepełnosprawnościami w latach 70. z perspektywy performatywnych

5 Zob. J. Rancière Estetyka jako polityka, przeł. J. Kutyła, P. Mościcki, Wydawnictwo Krytyki Politycznej, Warszawa 2007. 
koncepcji podmiotu ${ }^{6}$, to można postawić tezę, że zainicjowane wówczas działania o charakterze politycznym, prowadzące do rekonfiguracji podziału zmysłowości, nie są efektem wyłonienia się określonej grupy i jej autodefinicji jako grupy marginalizowanej, ale odwrotnie - że to akty i akcje podejmowane i powtarzane w przestrzeni publicznej, w przestrzeni tego, co wspólne, doprowadziły do wyłonienia się nowego podmiotu społecznego.

Wśród stosowanych strategii działania i walki o prawa szczególne miejsce - ze względu na ich performatywną siłę - zajmują różne formy protestu: od manifestacji po okupację. Performatywna siła wiąże się tu z jednej strony z poczuciem podmiotowej sprawczości, a z drugiej - z kategorią skuteczności podejmowanych akcji. Myślenie o niepełnosprawności w ścisłym związku z kategorią performatywności pozwala ukazać konstrukcyjny, społecznie wytwarzany i procesualny charakter tej pierwszej i jednocześnie nie stracić z pola widzenia jej cielesnego, materialnego i indywidualnego charakteru, związanego z różnymi konkretnymi formami ucieleśnienia7. Protesty, mani-

6 Można tu przywołać chociażby koncepcję performatywności płci sformułowaną przez Judith Butler, zakładającą, że płeć kulturowa jest efektem powtarzanych praktyk społecznych, realizacją pewnego skryptu i procesem aktualizacji poprzez działanie określonego stylu definiującego podział płci w danym kontekście społeczno-kulturowym. Ów realizowany w szeregu powtórzeń skrypt ma charakter normatywizujący, jednak Butler wskazuje również na odmienne praktyki, mające potencjał subwersywny wobec wytwarzanej i naturalizowanej normy, ujawniające jej konstruktywny charakter. Zob. J. Butler Uwikłani w płeć. Feminizm i polityka tożsamości, przeł. K. Krasuska, Wydawnictwo Krytyki Politycznej, Warszawa 2008.

7 Pojęcie performansu i performatywności we współczesnej humanistyce jest oczywiście niezwykle złożone i niejednorodne, będzie też inaczej definiowane w zależności od tego, czy punkt ciężkości przesuniemy w sferę działań artystycznych, praktyk rytualnych, widowisk kulturowych czy performansów społecznych, w tym związanych z procesem wytwarzania określonych tożsamości i podmiotów społecznych. Pojęcie to należałoby oczywiście zniuansować w odniesieniu do niepełnosprawności rozumianej tutaj nie jako esencjalnie pojmowana właściwość ciała, umysłu czy psychiki, ale jako wytwarzana społecznie kategoria kulturowa. Ze względu na zakres tego tekstu w tym miejscu odwołuję się do pewnych ogólniejszych pojęć i założeń warunkujących tendencję nazywaną zwrotem performatywnym w humanistyce. Zwrot ten, poza tym, że jest pewną tendencją teoretyczną, jest też uznawany za odpowiedź na zmiany w polu społecznym związane z wyłanianiem się nowych, działających w nim podmiotów (zarówno ludzkich, jak i nieludzkich). Jest on ściśle powiązany z tak zwanym zwrotem ku sprawczości, a także przesunięciem punktu ciężkości w sferę działania i odgrywania, w ramach których nie tyle dokonuje się ekspresja, ile zachodzi proces wytwarzania znaczeń, tożsamości, podmiotowości. Kategoria performatywności w odniesieniu do podmiotowości pozwala również wyjść poza opozycję między sygnalizowanym przeze mnie podejściem konstruktywistycznym a esencjalizmem. Zob. np. E. Domańska „Zwrot performatywny” we współczesnej humanistyce, "Teksty Drugie" 2007 nr 5. 
festacje, okupacje podejmowane przez osoby z niepełnosprawnościami można widzieć zatem jako performanse walki i oporu nakierowane na określone cele polityczne i wskazujące - poprzez bezpośrednie działania w przestrzeni publicznej - na mechanizmy społecznej opresji i wykluczenia, ale też jako performanse tożsamościowe, dla których medium jest ciało. Poprzez jego fizyczną obecność i aktywność ujawnia się nie tylko system wykluczeń ze świata urządzonego na potrzeby jednostki znormatywizowanej, ale też w tym nieraz ostrym zderzeniu nieprzystosowanej rzeczywistości i konkretnych ciał $\mathrm{z}$ wielką siłą objawia się różnorodność form ucieleśnienia.

Chciałabym przyjrzeć się owym performatywnym działaniom aktywistycznym, przywołując kilka wybranych, znamiennych przykładów, by zastanowić się nad kategorią widzialności jako jednym z kluczowych czynników warunkujących rozpoznanie działań tej określonej grupy jako działań o charakterze politycznym. Kategoria widzialności pozostaje tu w ścisłym związku z kategorią performatywności. Chodzi bowiem nie tylko o to, by być widocznym, zostać zauważonym, a więc przyciągnąć spojrzenie i uwagę, ale by poprzez określone działania wytwarzać i definiować pole widzialności w taki sposób, żeby zdekonstruować i zmienić stereotypowe spojrzenie na niepełnosprawność, co jest krokiem wstępnym do wprowadzenia dalszych konkretnych zmian. Ważne jest tutaj uwzględnienie odbiorcy owego redefiniowanego i reaktualizowanego w kolejnych akcjach i aktach społecznego performansu niepełnosprawności, gdyż, jak podkreśla Marvin Carlson „performans jest zawsze performansem dla kogoś [...] - chociażby nawet [...] publicznością była czyjaś własna osoba"8. W omawianej tutaj sytuacji chodzi zarówno o same osoby z niepełnosprawnością, będące jednocześnie aktorami i odbiorcami działań aktywistycznych konsolidujących poczucie tożsamości i przynależności do określonej, wyłaniającej się w ramach tych działań grupy, jak i o tych członków społeczeństwa, którzy - w zetknięciu z tego typu działaniami w przestrzeni publicznej rozumianej jako pole widzialności i słyszalności - zmuszeni są do uwzględnienia obecności nowych podmiotów społecznych wytwarzanej przez nie same na ich własnych zasadach.

\section{Nowe rozumienie niepełnosprawności}

Rozumienie niepełnosprawności było w XX wieku zdominowane przez tak zwany model medyczny i model charytatywny. Pierwszy z nich ujmował ją

8 M. Carlson Performans, przeł. E. Kubikowska, PWN, Warszawa 2007, s. 29. 
w kategorii patologii, którą w miarę możliwości należy poddawać rehabilitacji czy korekcji w celu jak największego „odzyskania” sprawności i zbliżenia się do zakładanej normy. Drugi traktował ją jako osobiste nieszczęście, w którym należy wesprzeć jednostkę poprzez działania dobroczynne na jej rzecz, ale co znamienne - bez jej udziału: miała się ona stać biernym i wdzięcznym beneficjentem organizacji charytatywnych. Wjednym i drugim modelu mimo dzielących je różnic niepełnosprawność traktowana jest i przedstawiana jako kwestia osobista, której ciężar spoczywa na jednostce, a także jako stan negatywny i niepożądany zarówno z indywidualnego, jak i społecznego punktu widzenia, będący przedmiotem litości i troski. Stoi za nimi również założenie, że źródłem wszelkich problemów związanych z niepełnosprawnością jest choroba bądź uszkodzenie organizmu.

W latach 70. takie rozumienie niepełnosprawności zostaje stanowczo zakwestionowane i przez działalność protestacyjną aktywistów z niepełnosprawnościami, i przez towarzyszącą jej działalność intelektualną, polegającą na zmianie języka, a co za tym idzie - paradygmatów myślenia o niepełnosprawności i sposobów jej postrzegania zarówno przez osoby z niepełnosprawnościami, jak i pozostałych członków społeczeństwa.

Znacząca jest tutaj zmiana definicji niepełnosprawności zaproponowana i wprowadzona w Wielkiej Brytanii w tym czasie przez odwołujący się do lewicowych tradycji Związek Niepełnosprawnych Fizycznie przeciwko Segregacji [UPIAS - Union of the Physically Impaired Against Segregation]. Podstawą nowej definicji było rozróżnienie „niepełnosprawności” (disability) i „uszkodzenia” czy „niesprawności” (impairment), przy czym uszkodzenie uznawano za określoną właściwość ciała nietożsamą z niepełnosprawnością, którą traktowano jako kategorię warunkowaną społecznie i narzuconą przez określone mechanizmy społeczne, rozpoznawane jako opresyjne, prowadzące do izolacji i marginalizacji tych, którzy posiadają różnego typu uszkodzenia (niesprawności). „Niepełnosprawność jest czymś, co zostaje narzucone na nasze uszkodzenia przez bezpodstawną izolację i wykluczenie z pełnego uczestnictwa w życiu społecznym" - argumentowali twórcy UPIAS.

$\mathrm{Z}$ tej perspektywy to społeczeństwo jest głównym czynnikiem uniepełnosprawniającym konkretne osoby. Przyjęcie takiej perspektywy pozwoliło sformułować postulaty mające na celu doprowadzenie do określonej zmiany społecznej uwzględniającej potrzeby osób z niepełnosprawnościami. Żeby

9 UPIAS Podstawowe założenia na temat niepełnosprawności, przeł. M. Wieczorek, w: Niepełnosprawność i społeczeństwo, s. 122. 
tak się mogło stać, grupa ta musiała się uwidocznić jako grupa doświadczająca ucisku społecznego i domagająca się krytycznego spojrzenia na to, jak sposób urządzenia świata przyjmowany za neutralny, bo oparty na uniwersalizowanej i przezroczystej kategorii normy, wpływa na proces wykluczenia ogromnej części społeczeństwa. Chodzi nie tylko o organizację przestrzeni w sensie architektonicznym czy dostępność instytucji publicznych, ale też o mechanizmy rynkowe i ekonomiczne oparte na kategoriach produktywności i efektywności. Niebagatelną sprawą jest tu także kwestia tego, w jaki sposób postrzega się osoby z niepełnosprawnościami i jakie strategie reprezentacji przyczyniają się do podtrzymywania dyskursu zależności i niesamodzielności. Powraca zatem kwestia spojrzenia i redefinicji pola widzialności.

\section{Niewidzialność - hiperwidzialność. Spojrzenie (n)a niepełnosprawność}

Analizując twórczość aktorów i performerów z niepełnosprawnościami, Petra Kuppers sytuuje ich sceniczną obecność w paradoksalnej przestrzeni, w której dochodzi do napięcia i negocjacji pomiędzy dwiema kategoriami: niewidzialnością i hiperwidzialnością.

Artysta niepełnosprawny jest skazany na margines i niewidzialny - zepchnięty na boczny tor, z daleka od centrum aktywności kulturowej, odgórnie wpisany w dyskurs medycyny, terapii i bycia ofiarą. Jednocześnie osoby z fizycznymi uszkodzeniami są także w dwójnasób widoczne, nieustannie definiowane poprzez własną fizyczność. Artysta z fizyczną niepełnosprawnością jest zatem zmuszony do poruszania się pomiędzy dwoma obszarami kulturowego znaczenia: jest niewidzialny jako czynny uczestnik sfery publicznej oraz hiperwidoczny i natychmiastowo kategoryzowany

- stwierdza Kuppers ${ }^{10}$. Zdanie to można odnieść nie tylko do sfery działań artystycznych, ale również do obecności osób z niepełnosprawnością w przestrzeni publicznej. Obecność ta sytuuje się między dwiema wyróżnionymi przez Kuppers kategoriami: niewidocznością związaną z marginalizacją, a także instytucjonalną izolacją osób z niepełnosprawnościami oraz

10 P. Kuppers Dekonstrukcja obrazów. Performatywność niepełnosprawności, przeł. K. Gucio, w: Odzyskiwanie obecności. Niepełnosprawność w teatrze i performansie, red. E. Godlewska-Byliniak, J. Lipko-Konieczna, Wyd. Fundacja Teatr 21, Warszawa 2017, s. 17. 
hiperwidzialnością w sytuacji, gdy wkraczają one w przestrzeń publiczną. Hiperwidzialność warunkowana jest przy tym paradoksalnie przez ową ugruntowaną przez XX-wieczne praktyki niewidoczność.

Zarówno społeczna niewidzialność, jaki hiperwidzialność stanowią problem, z którym zmagają się osoby z niepełnosprawnością. Kategorie te niejednokrotnie stają się przedmiotem swoistej negocjacji z widzami. W jej ramach toczy się gra o spojrzenie, a raczej próba przekroczenia jego ograniczeń związanych z funkcjonowaniem klisz, przez których pryzmat postrzega się niepełnosprawność. Chodzi więc często o to, by przekierować spojrzenie i uwagę widza w taki sposób, by można było przekroczyć hiperwidzialność niepełnosprawności i przejść do innych kwestii. Ale też w ramach strategii podejmowanych przez artystów hiperwidzialność może zostać wzmocniona, stając się narzędziem w rękach performera czy aktora, a nie efektem piętnującego spojrzenia. Wiąże się to z przejęciem kontroli nad reprezentacją własnego ciała i kondycji, nad definicją własnej obecności w takiej a nie innej przestrzeni, co stanowi warunek wstępny do przejścia od Goffmanowskiej logiki piętna definiującego zranioną tożsamość tego, kto podlega napiętnowaniu za sprawą uprzedzonego i opresyjnego spojrzenia innych, do logiki upodmiotowienia, która pociąga za sobą odmienne rozumienie zaangażowania po obu stronach relacji opartej na spojrzeniu.

Można postawić tezę, że osoby z niepełnosprawnościami, które podejmują bezpośrednie akty obywatelskiego protestu czy nieposłuszeństwa w przestrzeni publicznej, stają się w szczególny sposób hiperwidzialne - ich widoczność jest bowiem wzmocniona przez rodzaj aktywności odbiegającej od tego, czego społeczeństwo zwykło spodziewać się po osobach uznawanych za niesamodzielne, bezwolne czy bezsilne. Hiperwidzialność staje się tu jednak sprzymierzeńcem w walce o prawa, a odzyskiwana w ramach kolejnych akcji protestacyjnych obecność staje się obecnością polityczną. Spojrzenie, które w innych kontekstach mogłoby zostać uznane za piętnujące gapienie się, w ramach wspominanych przez Kuppers działań artystycznych czy - tutaj performansów społecznych jest przyciągane celowo i na nowo definiowane.

Warto przywołać w tym miejscu rozważania Rosemarie Garland-Thomson:

Każdemu z nas zdarza się gapić. Jest to wzrokowa reakcja na coś, czego nie spodziewaliśmy się zobaczyć, nowości bowiem przyciągają nasz wzrok. Gapienie się to coś więcej niż zwykłe patrzenie - to natężone spojrzenie spowodowane dużym zainteresowaniem tym, co widzimy [...]. Gapimy się wówczas, kiedy zwykłe patrzenie zawodzi, a jednocześnie chcemy 
dowiedzieć się więcej. Gapienie się jest zatem gestem proszącym o wyjaśnienie - to gest, który domaga się historii. [...] Gapienie się rozpoczyna się od reakcji na impuls, która dzięki ciekawości może zmienić się w zaangażowanie. ${ }^{11}$

W myśl tej logiki działania osób z niepełnosprawnościami będące elementem ich bezpośredniej walki o zmianę społeczną i widoczną formą ich społecznego zaangażowania, przyciągając uwagę innych, mogły wzbudzić nie tylko ich zainteresowanie, ale i zaangażowanie prowadzące do wsparcia w walce o wysuwane przez aktywistów postulaty. Efektem performatywnej siły protestów mogła być zatem przemiana przynajmniej części gapiów w aktywnych sojuszników zmiany. Ale też na bardziej podstawowym poziomie - obecność i widzialność osób z niepełnosprawnościami w przestrzeni publicznej za sprawą podejmowanych przez nie akcji uwidaczniała i uświadamiała problem, który był niezauważany lub od którego celowo odwracano wzrok - że niepełnosprawność jest nie tylko kwestią indywidulaną, ale efektem działania społecznych urządzeń i praktyk, w tym tych związanych ze stereotypowymi strategiami patrzenia i klasyfikowania.

\section{Protesty, manifestacje, okupacje}

Przypomnijmy, że bezpośrednią inspiracją dla ruchu osób z niepełnosprawnościami w USA, na co wskazuje Tom Shakespeare, był ruch na rzecz praw obywatelskich i ruchy feministyczne z lat 6o., a stosowane przez nie strategie wykorzystywane były również przez aktywistów brytyjskich. Richard K. Scotch, przywołując amerykańską historię walki o prawa osób z niepełnosprawnościami, przypomina natomiast, że „idea praw [im] przysługujących [...] zakorzeniona jest w od dawna ustalonych amerykańskich ideałach autonomii i samostanowienia. Odniesienie tych ideałów do osób niepełnosprawnych jest jednak relatywnie nowe"12. O ile wymienione przez Scotcha kategorie autonomii i samostanowienia nie są oczywiste z perspektywy historii niepełnosprawności i jej reprezentacji (ich ustanowienie można

11 R. Garland-Thomson Staring. How we look, Oxford Univeristy Press, Oxford-New York 2009, s. 3 (przekład Katarzyny Ojrzyńskiej, którym się posługuję, ukaże się wkrótce nakładem Fundacji Teatr 21).

12 R.K. Scotch "Nothing about us without us": disability rights in America, "OAH Magazine of History" 2009, vol. $23 \mathrm{nr} 3$, s. 17. 
postrzegać jako jeden z czynników sprzyjających społecznemu wykluczeniu tych, którzy nie spełniali stawianych przez nie wymogów, jak pokazuje Rosemarie Garland-Thomson ${ }^{13}$ ), o tyle nabierają one szczególnego znaczenia i zostają niejako zredefiniowane w ramach tworzącego się ruchu osób z niepełnosprawnościami. Bo choć w XIX wieku i przez większość wieku XX, jak stwierdza Scotch, „osoby niepełnosprawne były postrzegane jako zależna, marginalna, i często wątpliwa moralnie mniejszość, która wymagała specjalnej opieki, ale którą trzymano z dala od życia publicznego poprzez mieszankę dobroczynności i społecznego wykluczenia", to później, głównie za sprawą politycznej działalności owej mniejszości, zmieniło się postrzeganie samej niepełnosprawności - osoby z niepełnosprawnościami „mogą być traktowane jako posiadające sprawczość i zdolność do kształtowania własnego życia"14.

Niezależnie od różnic dzielących ruchy w USA i Wielkiej Brytanii w pierwszym okresie walki o prawa i tu, i tu stosowano strategie działania bezpośredniego i organizowano kampanie, których punktem wyjścia były często podobne hasła i postulaty. Warto przywołać kilka konkretnych akcji, by przyjrzeć się owym strategiom i postulatom.

\section{a) Strajk okupacyjny 504}

Akcja znana jako „504 sit-in" rozpoczęła się 5 kwietnia 1977 roku i przybrała charakter wielodniowej okupacji budynku Ministerstwa Zdrowia, Edukacji i Pomocy Społecznej w San Francisco; dziś jest uznawana za najdłuższą pokojową okupację budynku rządowego w USA ${ }^{15}$. Poprzedziły ją demonstracje odbywające się tego dnia przed lokalnymi biurami tegoż ministerstwa w kilku dużych miastach USA: od Atlanty przez Boston, Chicago, Dallas, Denver, Filadelfię, Nowy Jork, Seattle po Waszyngton ${ }^{16}$. W kilku wypadkach protestujący zajęli również budynki ministerstwa, jednak większość akcji okupacyjnych zakończyła się po kilku lub kilkudziesięciu godzinach z powodu działań strony

13 Zob. R. Garland-Thomson Extraordinary Bodies: Figuring Physical Disability in American Culture and Literature, Columbia University Press, New York 1996.

R.K. Scotch "Nothing about us without us", s. 17.

Zob. B. Shoot The 1977 disability rights protest that broke records and changed laws, "Atlas Obscura" 09.11.2017, https://www.atlasobscura.com/articles/504-sit-in-san-francisco-1977disability-rights-advocacy (30.11.2019). 
rządowej zmierzających do przerwania protestu ${ }^{17}$. Jedynie w San Francisco udało się kontynuować go dopóty, dopóki nie zostały osiągnięte zakładane cele. Protestujący żądali wprowadzenia w życie regulacji dotyczących ustępu 504 Rehabilitation Act z 1973 roku. Znalazł się tam zapis o zakazie dyskryminacji osób z niepełnosprawnościami oraz ich wykluczania z powodu braku dostępu do instytucji publicznych.

Od numeru ustępu wspomnianego dokumentu wzięła nazwę okupacja w San Francisco. We wszystkich innych miastach protesty skończyły się po mniej więcej jednym dniu. W San Francisco grupa ponad 100 niepełnosprawnych aktywistów przedostała się do Ministerstwa Zdrowia i zajęła część jego biur na 26 dni. Grupa okupująca była bardzo zróżnicowana, znalazły się w niej osoby głuche, niewidome, poruszające się na wózkach, używające kul, doświadczające różnego stopnia niepełnosprawności. Część z nich potrzebowała tłumaczy bądź asystentów, którzy im towarzyszyli. Na zewnątrz przez cały czas okupujących wspierali ludzie dbający nie tylko o aprowizację, ale też o stałe zwracanie uwagi (w tym uwagi mediów) na protest i jego postulaty.

Na znaczenie przekazów medialnych i charakteru propagowanych obrazów protestu zwraca uwagę Paul K. Longmore: „Media z rejonu zatoki San Francisco i krajowe serwisy informacyjne relacjonujące okupację dzień po dniu rozpowszechniły zdjęcia osób niepełnosprawnych zaangażowanych w obywatelskie nieposłuszeństwo w poszukiwaniu swoich praw"18. Dodaje również, że „aktywiści z powodzeniem przekonali większość mediów do przedstawienia swojej sprawy jako kwestii praw obywatelskich, jako walki pomiędzy zwykłymi osobami niepełnosprawnymi a federalnymi biurokratami, którzy próbowali «ukraść nasze prawa obywatelskie»"19.

W czasie okupacji 504 osoby protestujące w budynku ministerstwa musiały mierzyć się nie tylko z niewygodami, ale też ze strategiami strony rządowej zmierzającymi do jak najszybszego zakończenia protestu - łącznie z odcinaniem linii telefonicznych i ogłaszaniem fałszywych alarmów

P. Longmore wskazuje, że z powodu głodu po ponad dobie została między innymi zawieszona okupacja w Waszyngtonie. Zob. P. Longmore The disability rights moment, s. 106-107. Joseph A. Califano - ówczesny minister zdrowia, edukacji i pomocy społecznej, którego biuro zajęli protestujący w Waszyngtonie, poza ograniczaniem dostępu do jedzenia, nakazał również odcięcie linii telefonicznych i wprowadzenie zakazu wchodzenia do budynku lub jego opuszczania. Zob. m.in. S. Bonney History of 504 passage, w: 20th anniversary. Victorious 504 sit-in for disability civil rights, Celebration and Commemoration Committee, San Francisco 1997, s. 9-12. 
bombowych przez służby $\mathrm{FBI}^{20}$. Okupujący nie dali się rozproszyć. Po kilkunastu dniach wyłonili spośród siebie grupę reprezentantów, która udała się do Waszyngtonu, by spróbować bezpośredniego nacisku na decydentów w sprawie wspomnianych regulacji. Bez owych regulacji, ciągle odkładanych i odwlekanych przez cztery lata dzielące przyjęcie Rehabilitation Act od protestu, zapisy o zakazie dyskryminacji ze względu na niepełnosprawność pozostawały martwe. Ostatecznie udało się doprowadzić do ich podpisania 28 kwietnia 1977 roku. Część okupujących pozostała w budynku jeszcze jakiś czas, stąd według najczęstszych szacunków określa się długość protestu na 26 dni. Dwadzieścia sześć dni w budynku nieprzystosowanym do potrzeb osób z niepełnosprawnościami, w bardzo ciężkich warunkach, ale też w atmosferze solidarności i równości, która pozwoliła przetrwać ten czas, stawić opór władzy i przeforsować jeden z głównych postulatów. Przyjęcie wspomnianych regulacji nie rozwiązało oczywiście wszystkich problemów, ale mówi się, że okupacja ta była istotnym krokiem na drodze do uchwalenia w 1990 roku najważniejszego dziś dla osób z niepełnosprawnościami w Ameryce dokumentu - Americans with Disabilities Act (ADA). W międzyczasie w kolejnych latach odbywały się regularne protesty i akcje, w ramach których osoby z niepełnosprawnościami ukonstytuowały się jako znacząca siła polityczna.

Paul K. Longmore podaje cztery powody, dla których okupację 504 uznaje za jeden z punktów zwrotnych w historii aktywizmu i walki o prawa osób $\mathrm{z}$ niepełnosprawnościami. Po pierwsze, protest ten dokonał redefinicji problemów, z którymi mierzą się osoby z niepełnosprawnościami, ujął je bowiem przede wszystkim w kategoriach społecznych, a nie medycznych i wskazał, że jedną z największych barier stanowią panujące przesądy, stereotypy i dyskryminacja. Po drugie, organizatorzy protestu nawiązali współpracę na szeroką skalę z innymi organizacjami walczącymi o prawa obywatelskie ${ }^{21}$. Po trzecie, protest miał charakter inkluzywny i pomógł wydobyć to, co wspólne dla ruchu, stawiając na aktywizm działający w poprzek różnych niepełnosprawności. Po czwarte, choć nie było to jego celem, przyniósł konkretne pozytywne efekty w polu związanym z polityką tożsamościową - przyczynił się do przełamania obrazu osoby z niepełnosprawnościami jako słabej, wytwarzając pozytywną tożsamość nieopartą na kategorii braku . „Przyjmując

Zob. np. B. Blanchard One of many, w: 20th anniversary, s. 34.

W tym kontekście przywołuje się najczęściej wsparcie, które protestującym zapewniały z zewnątrz Czarne Pantery, dbające w czasie okupacji o aprowizację.

Zob. P.K. Longmore The disability rights moment, s. 109-110. 
wojowniczą taktykę innych ruchów społecznych, osoby z niepełnosprawnościami pokazały społeczeństwu - i sobie - że nie są słabe, ale silne, nie niekompetentne, ale wykwalifikowane, nie bezradne, ale pełne mocy"23, pisze Longmore. Znaczenie szerokiej koalicji, będącej zarazem jedną z przyczyn i efektem sukcesu protestu 504, podkreślają także sami jego organizatorzy. Kitty Cone przypomina na przykład, że koalicja kryzysowa, która wzięła na siebie trud organizacji protestu w różnych miastach w USA, składała się z organizacji reprezentujących wszystkie rodzaje niepełnosprawności i rodziców dzieci z niepełnosprawnościami i że była ona wspomagana przez cały czas trwania protestu przez liczne środowiska - od organizacji gejowskich działających w San Francisco po Radę Kościołów, od Czarnych Panter po Fundację McDonalda - co dawało protestującym poczucie dużego poparcia ${ }^{24}$. Ale, co równie ważne, jak podkreśla Cone: „społeczeństwo zaczęło postrzegać nas inaczej; demonstrantów walczących o prawa obywatelskie z trudem dawało się utożsamić z obiektami działalności charytatywnej i współczucia, które stanowiły dominujący obraz naszych ludzi w tamtym czasie"25.

\section{b) Capitol Crawl}

Niewątpliwie na tego rodzaju wyzwaniu rzuconym dominującym obrazom niepełnosprawności opierała się siła wielu akcji protestacyjnych podejmowanych przez osoby z niepełnosprawnościami, w tym tej z 1990 roku, znanej jako Capitol Crawl, której realne znaczenie bywa dziś kwestionowane bądź niuansowane, ale której wymiar symboliczny jest nie do przecenienia.

Capitol Crawl opisuje się jako akcję, która przyczyniła się do szybszego podpisania ADA, najważniejszego dokumentu regulującego prawa osób z niepełnosprawnościami w USA. Jak zauważa Lennard J. Davis, ,ilekroć ktoś zastanawia się nad aktywizmem i ADA, jeden obraz przychodzi mu na myśl. Czarno-biała fotografia przedstawiająca osoby z niepełnosprawnościami czołgające się w górę po schodach Kapitolu"26. Badacz podkreśla w ten sposób sugestywność i siłę tego obrazu, a także - dodajmy - performatywnego

23 Tamże, s. 110.

24 Zob. K. Cone Keys to Victory, w: 2oth anniversary, s. 13.

25 Tamże, s. 14 .

26 L.J. Davis Enabling acts. The hidden story of how the Americans with Disabilities Act gave the largest US minority its rights, Beacon Press, Boston 2015, s. 191. 
działania, które za nim stoi. „Skomponowany z ludzi w każdym wieku i z wszelkimi niepełnosprawnościami realistyczny i odważny obraz czołgania się rzuca siłę aktywizmu w twarz władzy"27, mówi Davis.

Dwunastego marca 1990 roku członkowie American Disabled for Attendant Programs Today (ADAPT), organizacji działającej na szeroką skalę na rzecz praw osób z niepełnosprawnościami na terenie USA, zebrali się na marszu protestacyjnym w Waszyngtonie. Dołączyli do nich członkowie innych miejscowych organizacji. Kilkaset osób zgromadziło się pod Białym Domem, by przejść pod Kapitol. Tam przyłączyli się kolejni, tworząc niemal tysięczny tłum. Wznoszono okrzyki, wśród których dominowało hasło „ADA now!" (ADA teraz!). Grupa zebrała się przed frontowymi schodami Kapitolu ${ }^{28}$. Kilkadziesiąt osób odłączyło się od tłumu i - porzucając wózki, kule i inne urządzenia wspomagające mobilność - zaczęło czołgać się w górę, pokonując z trudem kolejne stopnie. Wśród wspinających się była również ośmioletnia wówczas Jennifer Keelan, której wizerunek przyciągnął największą uwagę mediów. Keelan stała się niewątpliwą ikoną tego protestu. Davis wskazuje, że uczynienie z niej gwiazdy i postawienie w centrum w przekazach medialnych niekoniecznie miało jednoznacznie pozytywny wydźwięk dla samego ruchu i jego celów, zagrały tu bowiem dawne wyobrażenia: dziecko jako symbol niepełnosprawności, jego działanie jako bohaterski czyn oraz nadludzki wysiłek budzący i podziw, i współczucie. Jednak z drugiej strony - dodaje Davis - obraz ten zasadniczo różni się od promowanych przez akcje charytatywne i programy typu teleton ${ }^{29}$, wykorzystujących wizerunki dzieci z niepełnosprawnościami przede wszystkim do wzbudzenia litości, przedstawia bowiem osobę świadomie i dobrowolnie angażującą się w akcję o charakterze politycznym ${ }^{30}$. „Wiedziałam, że nie reprezentuję tylko siebie, ale całe moje pokolenie. Gdybym tego nie zrobiła, nikt z mojego pokolenia nie byłby reprezentowany", mówi Keelan w wywiadzie udzielonym kilkanaście lat później³

27 Tamże.

28 L.J. Davis wskazuje, że poza frontowym wejściem Kapitol byłzasadniczo dostępny. Zob. tamże, s. 192. Uznać jednak należy, że osiemdziesiąt kilka stopni prowadzących do głównego wejścia reprezentacyjnego budynku stanowiło wyjątkowo wymowny symbol niedostępności. Na temat teletonów piszę nieco więcej w dalszej części tekstu. L.J. Davis Enabling acts, s. 196.

31 Wywiad dostępny w YouTube na kanale organizacji It's Our Story - zob. ). Keelan Climbing The Capitol Steps for ADA, https://www.youtube.com/watch?v=HesvwnM-onE (04.01.2019). 
Z perspektywy czasu widać, że potencjalnie niejednoznaczny obraz czołgających się ciał wpisał się w historię ruchu jako działanie będące wyrazem determinacji, sprawczości i politycznej siły, a przy okazji stał się nie tylko znakiem walki o wprowadzenie konkretnych zmian legislacyjnych, ale też ucieleśniał - dosłownie - szeroko pojętą walkę o dostępność. Ten swoisty cielesny performans w przestrzeni publicznej o symbolicznym znaczeniu nie tylko wzmacniał postulaty zawarte w skandowanych hasłach i manifestach kierowanych do polityków, ale też budował dodatkowe sensy.

Rozciąnięte na schodach budynku ciała są wyraźnie niedopasowane: nieprzewidziane, niezgodne i zajmujące miejsce. [...] komunikują one to, czego same znaki i pieśni nie są w stanie przekazać: ten budynek, symbol rządów i demokratycznego obywatelstwa dla wszystkich wcielenie samego narodu - nie był zaprojektowany z myślą o osobach niepełnosprawnych ${ }^{32}$

stwierdza Aimi Hamraie w swej książce poświęconej projektowaniu uniwersalnemu. Badaczka uznaje, że akcja Capitol Crawl ukazała osoby z niepełnosprawnościami jako aktywnych obywateli, którzy za pomocą nowych taktyk ujawniali w dobitny sposób mechanizmy dyskryminacji ze względu na niepełnosprawność. Ustawa ADA, o której wprowadzenie walczyli protestujący, zawiera zapisy dotyczące między innymi zatrudnienia, dostępności transportu i budynków użyteczności publicznej, edukacji i wielu innych kwestii domagających się regulacji ze względu na działające mechanizmy wykluczenia. Jednak, jak zauważa Hamraie w nieco foucaultowskim duchu:

krytyczny wydźwięk tych taktyk [stosowanych przez aktywistów z niepełnosprawnościami - E.G.B.] wykraczał daleko poza ADA. Demonstracja dawała wyraz szczególnej niepełnosprawnościowej teorii architektury: wznoszone formy niosą ze sobą materialną retorykę, która ujawnia kulturowy podział wiedzy i władzy. Osoby niepełnosprawne przeciwstawiły się tym schodom, wykorzystując wcieloną mowę i przeżywaną wiedzę jako krytykę architektury. ${ }^{33}$ ta Press, Minneapolis-London 2017, e-book (sekcja: Introduction. Critical Access Studies). 
Wcielona mowa i przeżywana wiedza to elementy bezpośrednich działań o charakterze performatywnym ustanawiających żywą obecność w przestrzeni publicznej poddawanej w ten sposób krytyce i redefinicji. Obecność ta w ramach bezpośrednich działań ujawnia to, co niewidoczne, bo umyka uwadze nawet w czasach obowiązywania konkretnych rozwiązań legislacyjnych broniących praw osób z niepełnosprawnościami - prawa te nie zostaną w pełni wcielone w życie, dopóki mechanizmy dyskryminacji pozostaną przezroczyste. Dzięki akcjom protestacyjnym aktywistów z niepełnosprawnościami i ich dokumentacji stają się one - również poprzez wykorzystanie strategii hiperwidzialności - jawne i namacalne. Wiele z tych akcji dotyczyło kwestii dostępności.

\section{c) Dostępny transport}

Jednym z ważnych postulatów, które znalazły swój wyraz w szeregu konkretnych akcji i w Stanach Zjednoczonych, i Wielkiej Brytanii, było żądanie dostępności transportu. Stosowano tu takie strategie, jak blokowanie autobusów i dróg. W słynnych akcjach na Oxford Street w Londynie w latach 90. protestujący przykuwali się łańcuchami do autokarów ${ }^{34}$. Podobnych taktyk używali protestujący w USA. Co ważne, były to akcje o charakterze masowym i zorganizowanym. Liczne zdjęcia $\mathrm{z}$ archiwum Toma Olina, który od połowy lat 8o. dokumentuje akcje protestacyjne osób z niepełnosprawnościami w różnych miastach USA, pokazują swoistą masę krytyczną na wózkach kilkadziesiąt osób we wspólnym przejeździe głównymi ulicami, całe grupy blokujące autobusy. Towarzyszą im zawsze znamienne hasła żądające transportu dostępnego dla wszystkich.

Tego rodzaju masowej obecności nie da się zignorować, mimo że akcje spotykały się oczywiście z oporem władz poszczególnych miast, działaniami policji itd. Ich siłą było wyraźne wskazanie określonego problemu i ujawnienie, jak wielu ludzi dotyczy. To kwestia niebagatelna, jeśli wziąć pod uwagę, że osoby z niepełnosprawnościami, żyjące w izolacji, przez długi czas również same siebie nie postrzegały jako grupy. Wskazuje na to przykład przytoczony przez Olina, który oprócz tego, że był fotografem, pełnił też funkcję edukatora pracującego z osobami doświadczającymi wykluczenia. Na zajęciach pokazał grupie swoje zdjęcia z protestów. Jedna z młodych osób - jedyna w całej placówce, która jeździła na wózku - wyznała potem, że nie miała pojęcia, że jest

Zob. T. Shakespeare Samoorganizacja osób niepełnosprawnych, s. 35 . 
tylu ludzi podobnych do niej35. Olin tak skomentował tę reakcję i poruszenie wywołane przez obraz protestu:

Oczywiście ten dzieciak nigdy ich nie widział i nie mieliśmy wtedy ADA. Nikt [z niepełnosprawnością] nie pojawiał się poza domem. Miałem [w albumie] wycinek na temat akcji w San Francisco z magazynu „Time”, dotyczył grupy ADAPT, którą obserwowałem i której robiłem zdjęcia podczas akcji.„Time” nazwał ich „wojownikami na wózkach”.Ten dzieciak zobaczył to zdanie, po prostu się uśmiechnął i powiedział: „Mogę być wojownikiem na wózku inwalidzkim!".36

Opisywana przez Olina sytuacja to jeden z takich momentów, które mogą dać impuls do wyłonienia się świadomości przynależności do pewnej grupy. Grupy, która staje się widzialna i która domaga się głosu. Akcje dokumentowane przez Olina, podejmowane regularnie w całym kraju, jak też same fotografie ujawniają tutaj swoją sprawczą moc nie tylko na polu walki politycznej, ale też poprzez wprowadzenie zmiany w przestrzeni reprezentacji pociągającej za sobą proces wyłaniania się nowej, społecznej tożsamości osób z niepełnosprawnościami ${ }^{37}$.

\section{d) Akcja Stop Telethon}

Wyrazem walki o zmianę myślenia o niepełnosprawności i sposobów jej reprezentowania jest przeprowadzona w Wielkiej Brytanii akcja Stop Telethon, pokazująca różnicę, o której wspominał Shakespeare, a mianowicie większe nastawienie brytyjskich aktywistów nie tyle na włączenie w istniejące struktury, ile na zmianę obowiązujących paradygmatów, w tym sposobu, w jaki jest postrzegana i definiowana niepełnosprawność.

Teleton (od połączenia słów „telewizja” i "maraton”) to nazwa zbiórki funduszy na cele charytatywne poprzez wpłaty telefoniczne od widzów, którzy przez wiele godzin mogą śledzić program w telewizji. W czasie jego trwania

35 Zob. R. Gross \#ADA 25: Disability Rights through Tom Olin's Lens, National Endowment for the Arts, 23.07.2015, https://www.arts.gov/art-works/2015/ada25-disability-rights-through-tom-olins-lens (29.11.2019).

36 Tamże.

37 Por. tamże. Zob. również: J. Lipko-Konieczna Skuteczność obrazów, w: Niepełnosprawność i społeczeństwo, s. 21-31. 
prezentowano historie i wizerunki osób z niepełnosprawnościami (często dzieci) przede wszystkim z zamiarem wzbudzenia litości i współczucia. Akcje wymierzone w program miały pokazać, że osoby z niepełnosprawnościami potrzebują raczej praw społecznych, a nie wsparcia odwołującego się do tego typu uczuć, uznawanych przez dużą część aktywistów za dyskryminujące ze względu na to, że bazują na powielanych w ramach modelu charytatywnego obrazach słabości, bezwolności i zależności tłumaczonych kondycją osoby $\mathrm{z}$ niesprawnością. Protestujący zwracali uwagę na bariery społeczne, w tym bariery językowe i wynikające z takiego stereotypowego myślenia.

Jedną ze znamiennych akcji podjętych w ramach Stop Telethon był performans Tony'ego Heatona, który odbył się w czasie konferencji prasowej zorganizowanej w Dioramie przez London Disability Arts Forum. Konferencja była poświęcona sprzeciwowi wobec teletonu prowadzonego w 1992 roku przez stację ITV. W centrum sali stała rzeźba Shaken not stirred zbudowana z 1683 puszek do zbierania datków ustawionych w kształt piramidy. W pewnym momencie artysta wjechał na swoim wózku, rozbujał trzymaną nad głową protezę nogi obutą w glan i rzucił nią w piramidę, tak że puszki się rozsypały, po czym opuścił salę̨.

Akcja miała siłę krótkiego wstrząsu, działała za sprawą szoku, ale też symboliki wyrazu. Stanowi przykład na to, jak działania artystyczne mogą wspierać i współtworzyć aktywizm. Chociaż ich polityczność lokuje się gdzie indziej i wyraża się inaczej niż polityczność masowych akcji w przestrzeniach publicznych, mają one nie mniejszą siłę i nie mniejsze znaczenie dla budowy nowego obrazu niepełnosprawności, współtworzonego przez rozmaite formy aktywizmu.

\section{Postępowe obrazy, nowe koncepcje}

Tom Shakespeare, wskazując na teoretyczne słabości społecznego modelu niepełnosprawności wywodzącego się z działalności UPIAS - słabości widoczne z perspektywy czasu i niewykluczające niewątpliwych, przede wszystkim politycznych korzyści - stwierdza:

Chcąc wzmocnić tożsamość zbiorową, ruch osób niepełnosprawnych będzie musiał wypracować nowe podejście do kwestii uszkodzenia

38 Zob. Shaken not stirred. Opis pracy Tony'ego Heatona, w: Niepełnosprawność i społeczeństwo, s. 55 . 
(impairment) i procesu uświadamiania osób niepełnosprawnych. Czołową rolę odegrają tu kulturowe i artystyczne obrazy osób niepełnosprawnych, tworzone przez nie same, bowiem tylko z prowokujących obrazów, które nie stronią od sprzeczności, wyłonią się postępowe koncepcje. ${ }^{39}$

Przedmiotem krytyki stało się zbyt radyklane oddzielenie kategorii uszkodzenia rozumianego jako właściwość ciała od pojęcia niepełnosprawności. Nowsze ujęcia niepełnosprawności zmierzają często w kierunku uwzględnienia i rozpoznania różnorodnych form ucieleśnienia jako współtworzących doświadczenie niepełnosprawności. Przywołane przykłady działań pokazują jednak, że performatywny wymiar akcji protestacyjnych podejmowanych przez osoby z niepełnosprawnościami - wymiar bezpośredni, cielesny i materialny - od początku niuansował sposób rozumienia i przedstawiania niepełnosprawności w ramach aktywizmu z lat 70. i późniejszego: przesuwając punkt ciężkości na wymiar społeczny, kwestię praw obywatelskich i rozwiązań legislacyjnych, nie abstrahował od cielesności.

Przywołane przykłady akcji protestacyjnych miały także pokazać, jak w ich ramach wyłaniała się tożsamość osób z niepełnosprawnościami jako tożsamość grupowa i polityczna, związana z wkroczeniem w przestrzeń publiczną w roli pełnoprawnych podmiotów. Proces ten można widzieć jako proces (od) zyskiwania obecności i głosu pozwalający wprowadzić w przestrzeń tego, co wspólne, to, co w ramach dotychczasowej konfiguracji było niezauważalne, niesłyszalne czy nie do pomyślenia. Niezwykle ważny jest tutaj fakt, że nie chodzi jedynie o zmianę dokonującą się w sferze znaczeń i wyobrażeń, ale też w sferze konkretnych praktyk i działań i poprzez nie. To w ich ramach dokonuje się swoiste przekroczenie zarysowanej przez Petrę Kuppers dychotomii niewidzialności i hiperwidzialności. Niewidzialność oznacza, że osoba z niepełnosprawnością nie jest postrzegana jako pełnoprawny członek społeczności aktywnie współtworzący sferę publiczną. Hiperwidzialność wiąże się z procesem wpisywania niepełnosprawności w z góry ustanowione kulturowe wyobrażenia i narracyjne skrypty wzmacniające stereotypy. Wyobrażenia te oscylują w ramach dominujących, przywołanych wcześniej dyskursów: medycznego i charytatywnego, wokół kategorii słabości, zależności, bierności, nieszczęścia. Działania protestacyjne o charakterze społecznych performansów opartych na rekonfiguracji rozumianego po Rancière'owsku pola zmysłowości stanowią przykład wkroczenia ze 
sfery niewidzialności w sferę politycznej widoczności i słyszalności poprzez przełamywanie owych klisz i powoływanie nowych postępowych obrazów i koncepcji niepełnosprawności.

\section{Abstract}

\section{Ewelina Godlewska-Byliniak}

UNIVERSITY OF WARSAW

Disability and Activism: The Performative Power of Protest

The article explores the British and American tradition of disability activism, which has constituted a political force since the 1970s. The focus is on the performativity of protest activities, from demonstrations to sit-ins, and the notion of visibility which is crucial for achieving both political goals and for the emergence of a new positive group identity for people with disabilities. The strategies that activists use to break conventional medical and charitable representations of disability are presented through notable examples such as the 504 sit-in, Capitol Crawl, demonstrations on accessible transport and Stop Telethon.

\section{Keywords}

disability, protest, activism, performativity, hypervisibility, identity 